\title{
Vole population dynamics during the succession of a commercial forest in northern Finland
}

\author{
Sakeri Savola ${ }^{1,2, *}$, Heikki Henttonen ${ }^{1} \&$ Harto Lindén ${ }^{3}$ \\ 1) Finnish Forest Research Institute, Vantaa Research Centre, P.O. Box 18, Fl-01301, Finland \\ ( ${ }^{*}$ corresponding author's e-mail: sakeri.savola@helsinki.fi) \\ 2) Department of Biosciences, P.O. Box 65, Fl-00014 University of Helsinki, Finland \\ 3) Finnish Game and Fisheries Research Institute, P.O. Box 2, Fl-00790 Helsinki, Finland
}

Received 27 Apr. 2012, final version received 19 Sep. 2012, accepted 19 Oct. 2012

Savola, S., Henttonen, H. \& Lindén, H. 2013: Vole population dynamics during the succession of a commercial forest in northern Finland. - Ann. Zool. Fennici 50: 79-88.

Voles are the main prey item for many mammalian and avian predators. Changes in vole abundance affect predator density directly and influence small game species indirectly. To test the hypothesis that intensive management of boreal forests increases vole population density, we surveyed small mammals twice during 2006-2010 in forests representing four succession stages in Taivalkoski, northern Finland. We focused on the bank vole (Myodes glareolus) and the field vole (Microtus agrestis) and found that bank voles were more numerous in all stages of succession while densities of both species were lowest in young (24-30-year-old) forest stands. We also found that field voles increased after clear-cutting. Based on this study, current forestry practice in Finland has a clear impact on the abundance of these voles.

\section{Introduction}

Voles are abundant and common rodents of boreal forests in central and northern Fennoscandia, where they and their predators exhibit population cycles that take place over three- to five-year periods (Hansson \& Henttonen 1985, Hanski et al. 1991, Sundell et al. 2004). Many mammalian and avian predators prey mainly on voles, especially species of Microtus, as well as on other small mammals and birds. Predation pressure on small game species such as hares (Lepus spp.) and grouse (Tetraonidae) is likely influenced by vole population density with a lag (Angelstam et al. 1984, Hansson \& Henttonen 1989). Grouse numbers have declined in Finland for several decades (Lindén \& Rajala 1981,
Sirkiä et al. 2010), and Henttonen (1989) suggested that the decline could be related to higher densities of red fox and mustelids resulting from increased densities of the Microtus populations, due to high coverage of grassy clear cuts favouring Microtus voles.

Species of the vole genera Myodes and Microtus are common in Finland, and the most abundant species are the bank vole (My. glareolus) and the field vole (Mi. agrestis). It has been suggested that clear-cutting has a negative impact on primarily granivorous-folivorous species of Myodes but a positive one on predominantly folivorous species of Microtus (Hansson 1978, 1999). Clear-cutting is the most common felling practice in Finland (Peltola 2008), after which the ground vegetation typically changes 

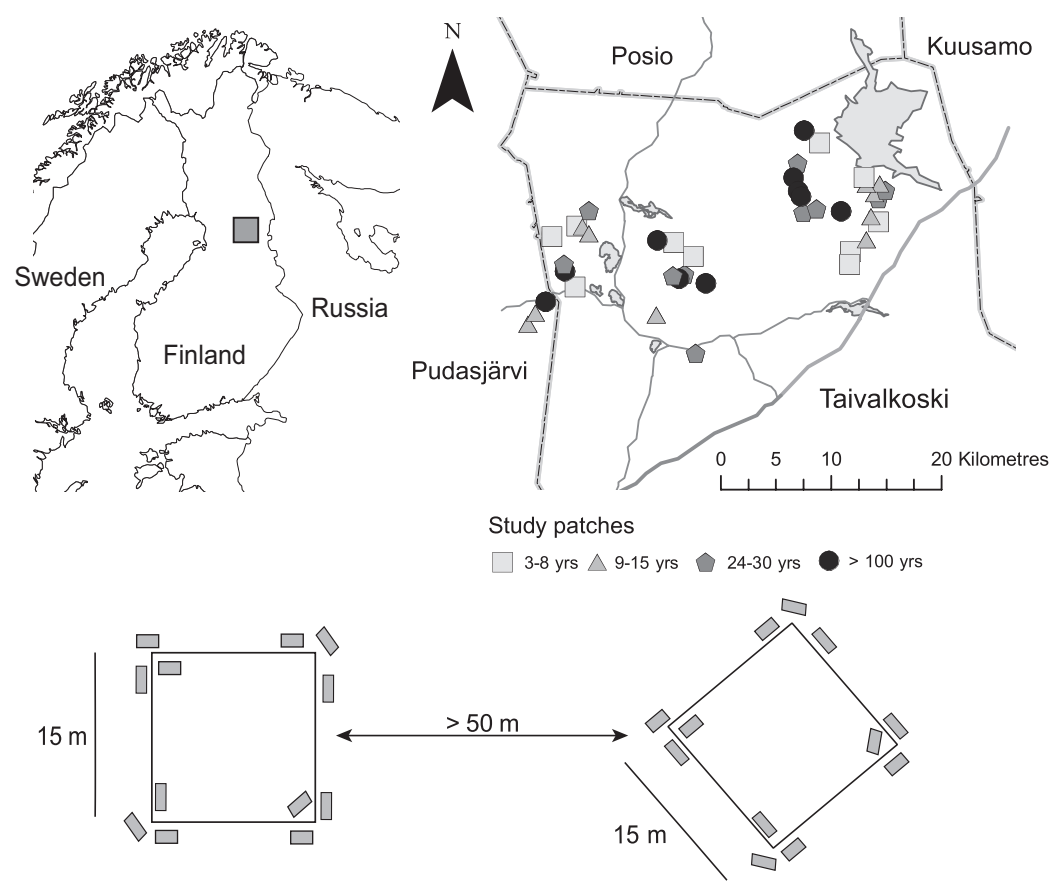

Fig. 1. Study area, forest stand locations, and small quadrat trapping arrangement. Five small quadrats per stand and 12 snaptraps per quadrat.

from one dominated by dwarf shrubs and mosses to one occupied by grasses (Uotila \& Kouki 2005). Finnish forests comprise $80 \%$ of the land area and are intensively managed in order to support an annual harvest of $2.7 \%$ of their total timber volume. According to the 10th National Forest Inventory, $17 \%$ of the Finnish forest is 1-20 years old (Peltola 2008). Thus, Finnish forestry has a large impact on the natural environment and a high potential to affect the native fauna and flora and their interactions.

With respect to population biology, species of Myodes and Microtus have a number of important ecological differences. In Microtus, breeding females have small home ranges that may overlap (Myllymäki 1977a, but see Erlinge et al. 1990) to create local densities that are 5-10 times higher than Myodes which have larger territories and breeding females with exclusive territories (Myllymäki 1977b, Henttonen 1980, 1987, Viitala \& Hoffmeyer 1985, Viitala 1987). Species of Microtus are the preferred prey for many mammalian predators such as red fox, stoat, least weasel (Lund 1962, Korpimäki et al. 1991), and Henttonen (1987, 2000) suggested that field voles in particular are essential for the reproduction of specialist predators.
The main aim of this work was to describe changes in vole density and community structure during forest succession after clear-cutting. Our hypotheses are: (1) field vole population density is inversely related to forest succession, i.e., decreases with forest age; (2) mature forest is the preferred habitat for the bank vole, but during population peaks they occur in forests of all succession stages; and (3) bank vole population density decreases when Microtus voles are present due to their aggressive behaviour during the reproductive season.

\section{Material and methods}

\section{Study design}

The study area was located near the municipality of Taivalkoski in northern Finland $\left(65^{\circ} \mathrm{N}, 28^{\circ} \mathrm{E}\right)$, close to the border of the northern and central boreal zones (Ahti et al. 1968) (see Fig. 1). The study area was a mosaic of managed forest stands at different successional stages as well as more mature forests mainly at higher elevations, partly included in the Syöte National Park. Lakes and rivers comprised $8 \%$ and cultivated 
$3-4$ years

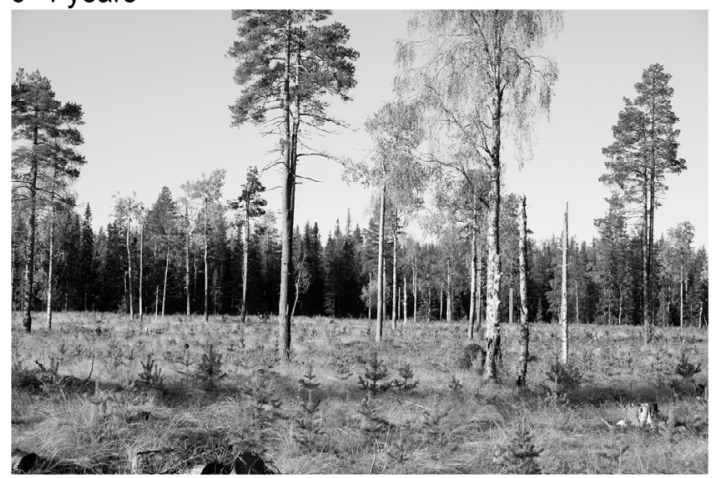

24-30 years

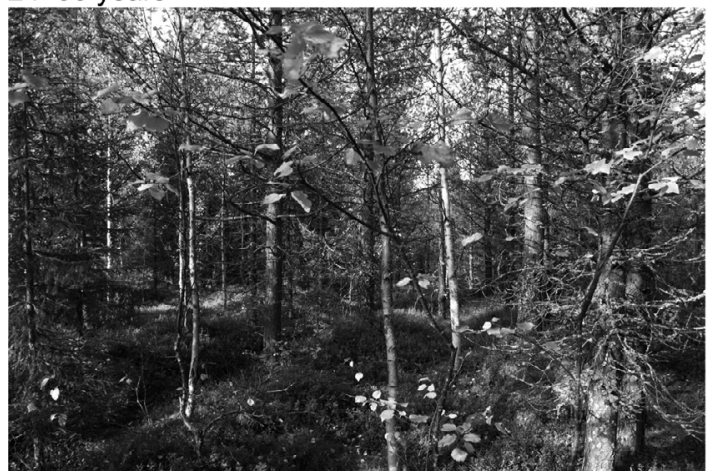

Fig. 2. Forest succession stages in 2006.

fields $0.6 \%$ of the study area (see 'Toimintaja tilinpäätöskertomus 2007' Municipality of Taivalkoski). The human population density in the municipality was $1.8 \mathrm{~km}^{-2}$ (http://www.tilastokeskus.fi/tup/kunnat/kuntatiedot/832.html).

Forty Myrtillus-type (MT: Cajander 1925) forest stands representing four stages of succession were selected in 2006 using the geographical information system of Metsähallitus (Finnish Forest and Park Service). MT forests were widespread in the study area, and the increased incidence of grasses after clear-cutting is more evident in these than in less productive types (Ferm \& Sepponen 1981). Ten replicate stands were sampled for each of the four stages: (i) trees that were 3-4 years old when the study began (hereafter "3-8 yr"); (ii) 9-11-year-old trees ("9-15 yr"); (iii) 24-26-year-old trees ("24-30 yr"), and; (iv) mature forests ("> $100 \mathrm{yr}$ ") (see Fig. 2).

Forest stands were 5-76 ha, and $>100 \mathrm{yr}$ stands were dominated by Norway spruce (Picea abies), whereas the younger forest stands were plantations of spruce or Scots pine (Pinus syl-
9-15 years

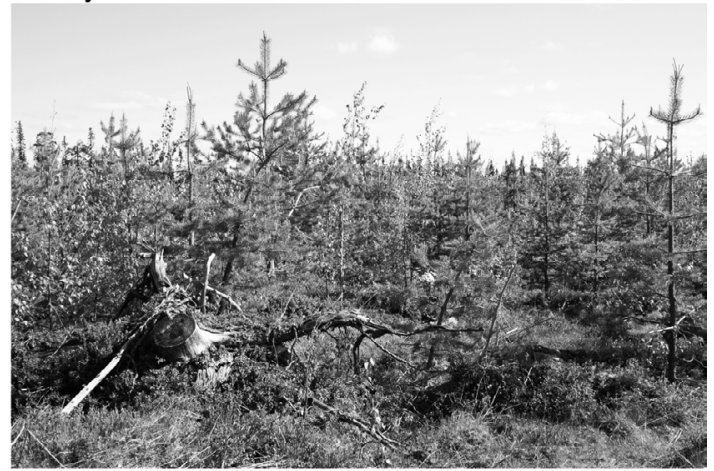

$>100$ years

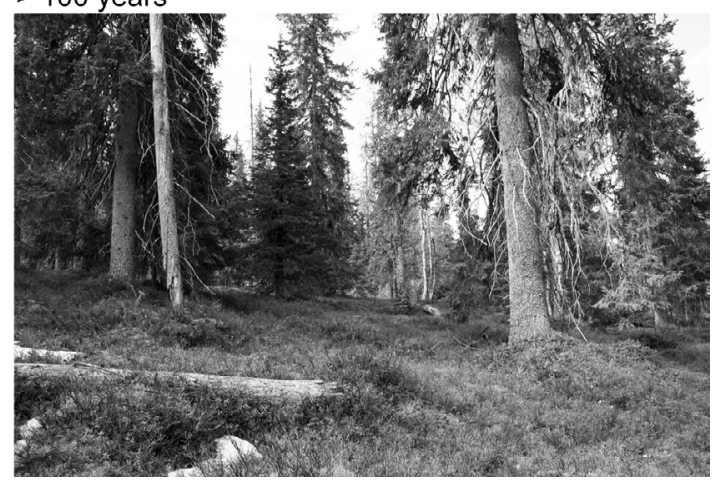

vestris) with some naturally regenerated birch (Betula spp.), aspen (Populus tremula) and rowan (Sorbus aucuparia). In the understory vegetation, mosses (Hylocomium splendens, Pleurozium schreberi and Dicranum spp.) together with bilberry (Vaccinium myrtillus) were dominant in mature forests. In 3-8-year-old stands, mosses were replaced by grasses (mostly Avenella flexuosa), willow herb (Chamerion angustifolium), and raspberry (Rubus idaeus). Grasses were still abundant in 9-15-year-old stands, but less so than in 3-8-year-old stands. In 24-30-year-old stands, mature trees shaded the ground resulting in a sparse undergrowth.

Rodents were trapped twice a year from 2006 to 2010, once in spring after snow-melt (MayJune) and again in autumn after the breeding season (September). Five small quadrats (Myllymäki et al. 1971) of $15 \times 15 \mathrm{~m}$ were placed in each stand. The minimum distance between quadrats was $50 \mathrm{~m}$, usually more (Fig. 1). Twelve snap-traps were baited with rye bread, placed in the corners of each quadrat (max. $2 \mathrm{~m}$ from the 
corner, three traps in each corner). Traps were set on day 1 , checked on day 2 and removed on day 3 . Each season consisted of 4800 trap nights, yielding a total of 48000 trap nights for the entire study.

\section{Statistical analyses}

Only animals that had overwintered were included in the spring analyses to avoid bias due to early breeding in some years, though only 14 young ones were found in spring trappings.

We classified vole population densities into two categories: low or high. The spring 2007, spring 2010, autumn 2006, autumn 2007 and autumn 2010 were classified as high and others as low. For each observation $i$, we included the vole-cycle phase $\left(\mathrm{Ph}_{i}\right)$ and season $\left(S_{i}\right)$ as fixed factors in every model. Intercepts of the hierarchical factors - quadrat (Quadrat; $j$ ) and area (Area; $k$ ) - were modelled as random effects. Additionally, we included observation (Obs; $i$ ) as a random effect accounting for overdispersion (Elston 2001). These factors are believed to account for small-scale spatial dependencies; for other variables included in alternative models see Table 1 . The variable abbreviations are:

AT: categorical factor of the stage of succession (3-8 yr, 9-15 yr, 24-30 yr, > $100 \mathrm{yr}$ ),

AA: a covariate of the areas age (coded 5.5, 12, $27,100)$,

AM: factor by which mature forests are separated from other types,

AS: a factor by which young forests $(3-8 \mathrm{yr}$, 9-15 yr) are separated from older ones (24-30 yr, > $100 \mathrm{yr}$ ),

M01: factor of presence/absence of field (Microtus agrestis) or root (Microtus oeconomus) voles in the small quadrat, and

LM: natural logarithm of the trapping index of field and root voles in the quadrat. Interactions are noted with an asterisk.

The corresponding main terms were included when the model contained an interaction.

We modelled the number of trapped voles per small quadrat using a GLMM (Generalized
Linear Mixed Model) with a log-link function and Poisson's error distribution. The general model can be expressed as

$$
\begin{gathered}
\ln \lambda_{i}=a+b_{1} P h_{i}+b_{2} S_{i}+f(i, \ldots)+\varepsilon_{i}+\gamma_{j}+\delta_{k}, \\
y_{i} \sim \operatorname{Poisson}\left(\lambda_{i}\right),
\end{gathered}
$$

where $a$ is the intercept, $b_{1}$ and $b_{2}$ are the effects of vole population phase and season, $f(i, \ldots)$ is the function of the other variables that vary among the models (1-18), while $\varepsilon_{i}, \gamma_{j}$ and $\delta_{k}$ are the normally-distributed random effects of observation $i$, quadrat $j$ and area $k$, respectively. All the random effects are assumed to have a zero mean and separately estimated variances.

We constructed 13 alternative models for the bank vole and for the field vole (Table 1), and evaluated them according to Akaike's Information Criterion (AIC: Burnham \& Anderson 2002). In addition, we examined the effect of Microtus presence on bank voles by comparing the most complex models B1-B13 (model B5) with 4 additional models (B14-B17; see Table 1) that were similar in structure but contained additional effects of Microtus. We selected model 5 to eliminate the effects of succession stage. We fitted all models with $\mathrm{R}$ statistical software version 2.9.2 (R Development Core Team 2009) and function glmer in package lme4 (Bates \& Maechler 2009) using a Laplace approximation.

\section{Ethics}

In accordance with the Act on the Use of Animals for Experimental Purposes (2006), the Finnish National Animal Experiment Board decided in May 2007 that snap-trapping is not an animal experiment and therefore no ethical permit is required. In case protected species were incidentally trapped during the rodent studies at the Finnish Forest Research Institute, a permit was granted by the Finnish Ministry of the Environment (23/5713/2001) to do so. However, none of the species trapped in this study were included in the current Finnish Red Book (2010: http://environment.fi/redlist). 


\section{Results}

During the five-year study, 3214 bank voles ( $M y$. glareolus), 27 grey-sided voles (My. rufocanus), 373 field voles (Mi. agrestis), 27 root voles (Mi. oeconomus), 33 wood lemmings (Myopus schisticolor), 790 common shrews (Sorex araneus), 37 Laxmann's shrews (S. caecutiens), four pygmy shrews (S. minutus) and three water shrews (Neomys fodiens) were caught. We focused on the two most common species of voles (My. glareolus and Mi. agrestis), which together comprised $98 \%$ of all rodents.
The most parsimonious model for bank vole abundance excluding the effects of Microtus presence, was model B5, including area type (succession stage) and interactions between area type and vole cycle phase as well as between area type and season (Table 1). This model was superior to all simpler models in terms of how succession stage affects bank vole densities. The difference in the AIC scores between model B5 and those including the effects of Microtus presence was (0.9-2.1). Thus, we had a weak or no evidence that presence of Microtus had an effect on bank vole densities. However, there was a weak

Table 1. Competing models and support for bank vole, bank vole including the effect of Microtus voles, and field vole. $\triangle \mathrm{AIC}$ are the differences in Akaike's information criterion as compared with the best model (AICs for models B5 and F2 equal 2221.815 and 891.225, respectively), $K$ is the number of estimated model parameters (and model degrees of freedom), and $\omega$ is the Akaike weight.

\begin{tabular}{|c|c|c|c|c|c|c|}
\hline & Model & Additional variables & $\triangle \mathrm{AIC}$ & $K$ & $\omega$ & Log(likelihood) \\
\hline \multicolumn{7}{|l|}{ Bank vole } \\
\hline & B5 & $\mathrm{AT} \times \mathrm{Ph}, \mathrm{AT} \times \mathrm{S}$ & 0 & 15 & 0.852 & -1095.91 \\
\hline & B3 & $\mathrm{AT} \times \mathrm{Ph}$ & 4.8 & 12 & 0.079 & -1101.28 \\
\hline & B13 & $A M \times P, A M \times S$ & 5.3 & 9 & 0.061 & -1104.55 \\
\hline & B9 & $\mathrm{AA} \times \mathrm{Ph}, \mathrm{AA} \times \mathrm{S}$ & 10.1 & 9 & 0.006 & -1106.94 \\
\hline & B11 & $\mathrm{AM} \times \mathrm{Ph}$ & 13.1 & 8 & 0.001 & -1109.44 \\
\hline & B4 & $\mathrm{AT} \times \mathrm{S}$ & 13.5 & 12 & 0.001 & -1105.64 \\
\hline & B12 & $\mathrm{AM} \times \mathrm{S}$ & 15.8 & 8 & $<0.001$ & -1110.81 \\
\hline & B7 & $\mathrm{AA} \times \mathrm{Ph}$ & 18.1 & 8 & $<0.001$ & -1111.98 \\
\hline & B8 & $A A \times S$ & 18.7 & 8 & $<0.001$ & -1112.25 \\
\hline & B2 & AT & 19.1 & 9 & $<0.001$ & -1111.47 \\
\hline & B10 & AM & 24.7 & 7 & $<0.001$ & -1116.28 \\
\hline & B6 & $\mathrm{AA}$ & 27.8 & 7 & $<0.001$ & -1117.83 \\
\hline & B1 & & 33.6 & 6 & $<0.001$ & -1121.71 \\
\hline \multicolumn{7}{|c|}{ Bank vole including } \\
\hline the effect of & B5 & $\mathrm{AT} \times \mathrm{Ph}, \mathrm{AT} \times \mathrm{S}$ & 0 & 15 & 0.346 & -1095.91 \\
\hline \multirow[t]{4}{*}{ Microtus voles } & B16 & $\mathrm{AT} \times \mathrm{Ph}, \mathrm{AT} \times \mathrm{S}, \mathrm{M} 01 \times \mathrm{S}$ & 0.9 & 17 & 0.223 & -1094.35 \\
\hline & B14 & $\mathrm{AT} \times \mathrm{Ph}, \mathrm{AT} \times \mathrm{S}, \mathrm{M} 01$ & 1.4 & 16 & 0.173 & -1095.61 \\
\hline & B15 & $\mathrm{AT} \times \mathrm{Ph}, \mathrm{AT} \times \mathrm{S}, \mathrm{LM}$ & 1.9 & 16 & 0.135 & -1095.85 \\
\hline & B17 & $\mathrm{AT} \times \mathrm{Ph}, \mathrm{AT} \times \mathrm{S}, \mathrm{LM} \times \mathrm{S}$ & 2.1 & 17 & 0.123 & -1094.94 \\
\hline \multicolumn{7}{|l|}{ Field vole } \\
\hline & $\mathrm{F} 2$ & AT & 0 & 9 & 0.486 & -436.61 \\
\hline & $\mathrm{F} 4$ & $\mathrm{AT} \times \mathrm{S}$ & 0.6 & 12 & 0.354 & -433.93 \\
\hline & F3 & $\mathrm{AT} \times \mathrm{Ph}$ & 3.4 & 12 & 0.088 & -435.32 \\
\hline & F5 & $\mathrm{AT} \times \mathrm{Ph}, \mathrm{AT} \times \mathrm{S}$ & 3.8 & 15 & 0.072 & -432.53 \\
\hline & $\mathrm{F} 10$ & AS & 22.4 & 7 & $<0.001$ & -449.83 \\
\hline & $\mathrm{F} 11$ & $\mathrm{AS} \times \mathrm{Ph}$ & 23.8 & 8 & $<0.001$ & -449.51 \\
\hline & F12 & $A S \times S$ & 23.9 & 8 & $<0.001$ & -449.59 \\
\hline & F13 & $\mathrm{AS} \times \mathrm{P}, \mathrm{AS} \times \mathrm{S}$ & 25.3 & 9 & $<0.001$ & -449.27 \\
\hline & F8 & $A A \times S$ & 28.3 & 8 & $<0.001$ & -451.77 \\
\hline & F9 & $\mathrm{AA} \times \mathrm{Ph}, \mathrm{AA} \times \mathrm{S}$ & 30.3 & 9 & $<0.001$ & -451.75 \\
\hline & $\mathrm{F} 6$ & $\mathrm{AA}$ & 33.5 & 7 & $<0.001$ & -455.36 \\
\hline & $\mathrm{F} 7$ & $\mathrm{AA} \times \mathrm{Ph}$ & 35.5 & 8 & $<0.001$ & -455.35 \\
\hline & $\mathrm{F} 1$ & & 64.6 & 6 & $<0.001$ & -471.90 \\
\hline
\end{tabular}




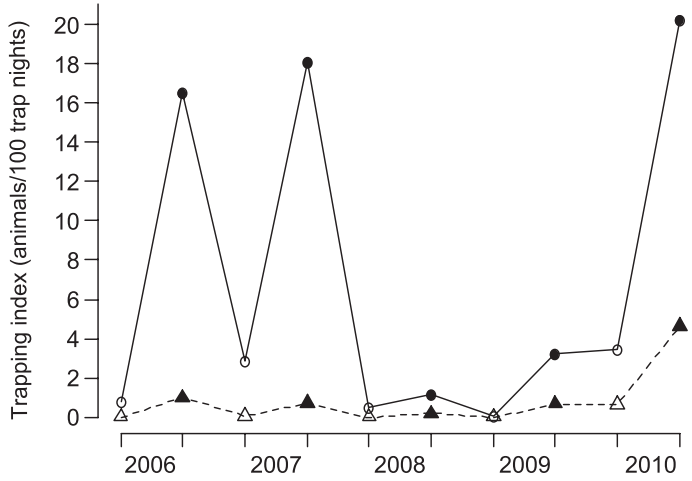

Fig. 3. Bank vole (solid line with circles) and field vole (dashed line with triangles) trapping indices (animals/100 trap nights) 2006-2010. Spring samples are marked with open symbols and autumn samples with filled symbols. A total of 4800 trap nights were completed per season.

tendency for the presence of Microtus to reduce bank vole abundance in spring. Overall, bank vole densities were highest in $>100$-year-old stands but the 9-15-year-old stands contained the second highest abundance overall and the highest abundance in 2006 (Table 1, Figs. 3 and 4). Bank vole densities in $>100$-year-old stands were especially high as compared with those in forests at other succession stages in spring and in years of low vole densities (Table 2).

The most plausible model for field vole abundance was F2, which included area type. The difference in AIC as compared with that of model $\mathrm{F} 4$, which also included an interaction between area type and season, was small (0.6; Table 1). Field vole densities were highest in 3-8-year-old stands and declined with each stage of succession (Table 3, Figs. 3 and 4). However, models containing a gradually declining trend did not perform well in comparison trials.

Total rodent density generally tracked that of bank voles except in 2010 during a peak in the number of field voles. Total rodent density was lowest in 24-30-year-old stands, where bank
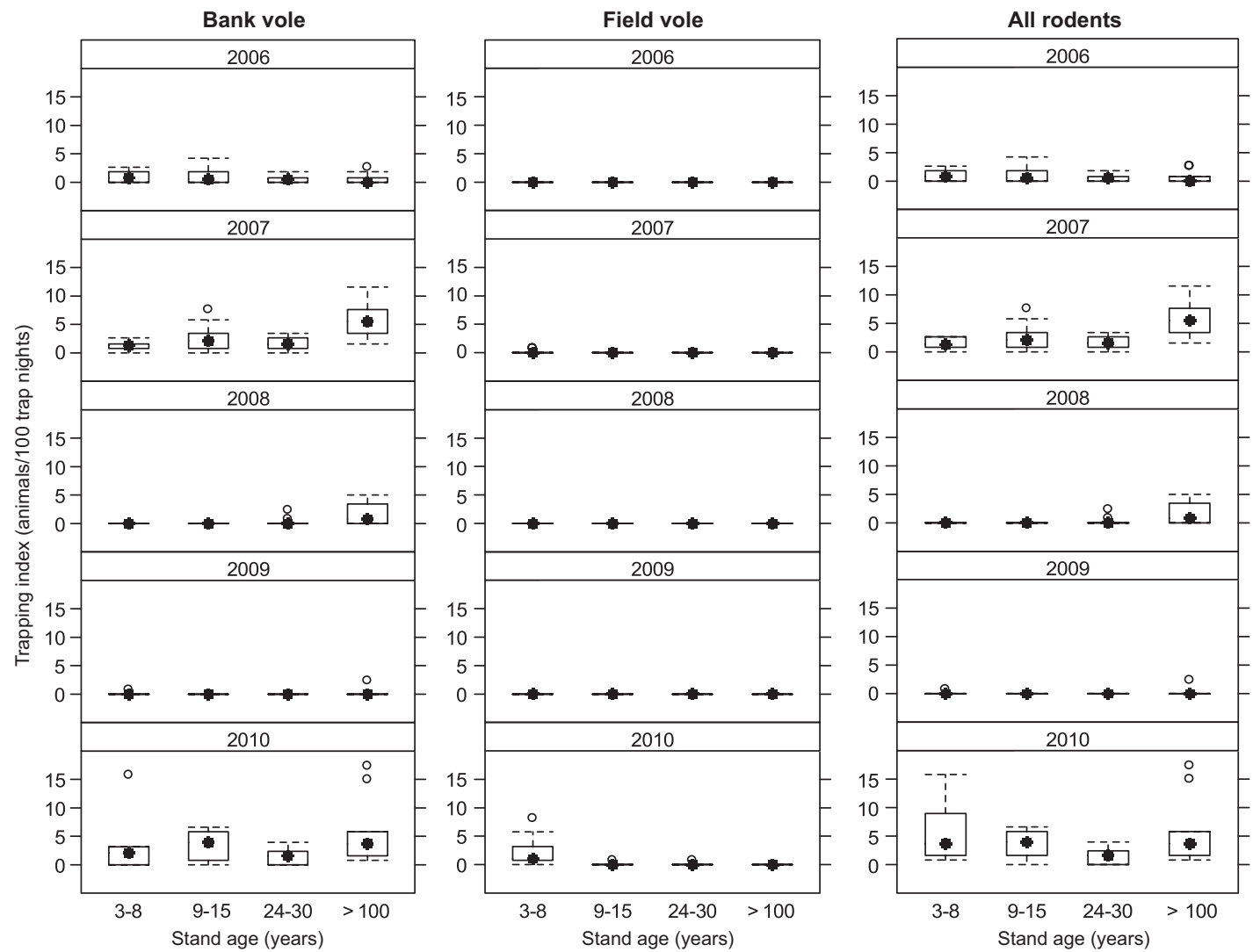

Fig. 4. Trapping indices (animals/100 trap nights) for bank vole, field vole, and all rodent species combined in trapping areas in spring. The smallest value, lower quartile, median, upper quartile and largest observation are shown. 
and field vole densities were also low (Figs. 4 and 5). During the autumn sampling, up to 16 bank voles were trapped from a single quadrat, whereas the maximum in spring was 8 . The maximum numbers of field voles trapped in autumn and spring were 10 and 4, respectively. Common shrews were evenly distributed among all succession stages. Root vole densities were highest in 3-8-year-old stands, and wood lemmings were found in every stage but almost half of all individuals (16 of 36) were trapped in $>100$-year-old stands. Similarly, grey-sided voles were trapped in younger stands but were most abundant (14 of 27) in >100-year-old stands.

The study period included two kinds of vole population peaks. Following the moderate peak seen during the autumn of 2006, vole numbers decreased dramatically during the winter and field vole densities were also low. The total vole index remained stable during the winters of 2009-2010 (Fig. 2). The abundance of field voles was markedly higher during the summer of 2010 than of 2007-2008 (Fig. 2). In some stands, field vole numbers were higher than those of bank voles.

Table 2. The best supported GLMM for the effects of forest age on the number of bank voles on small quadrats. Estimates are given on a logarithmic scale. SE is the standard error of each parameter estimate, $\sigma$ is the standard deviation attributable to random effects. The intercept stands for $>100 \mathrm{yr}$, Season Autumn and Phase High combination.

\begin{tabular}{clcc}
\hline Effects & Parameter & Estimate & SE \\
\hline Fixed & Intercept & 1.66 & 0.13 \\
& 3-8 yr & -0.47 & 0.18 \\
& 9-15 yr & -0.16 & 0.18 \\
& 24-30 yr & -0.76 & 0.18 \\
& Season Spring & -1.52 & 0.09 \\
& Phase Low & -1.81 & 0.10 \\
& 3-8 yr $\times$ Season Spring & -0.49 & 0.17 \\
9-15 yr $\times$ Season Spring & -0.32 & 0.15 \\
24-30 yr $\times$ Season Spring & -0.36 & 0.18 \\
3-8 yr $\times$ Phase Low & -0.18 & 0.17 \\
9-15 yr $\times$ Phase Low & -0.67 & 0.18 \\
24-30 yr $\times$ Phase Low & -0.65 & 0.22 \\
Random & N groups & $\sigma$ \\
& Quadrat:Area & 200 & 0.19 \\
& Area & 40 & 0.37 \\
& Observation & 2000 & 0.33
\end{tabular}

\section{Discussion}

As expected, field vole densities were highest in young succession stages, given that forest management practices such as clear-cutting increase the habitat suitable for field voles. However, it seems that the relationship between field vole density and forest succession is non-linear, with different patterns in spring and autumn and at different phases of the vole population cycle. Furthermore, there are long-term trends in cyclic periodicity of vole populations, and northern Finland was notable for its absence of cycles and low density of Microtus species since the early 1980s until 2009 (Henttonen et al. 1987, Henttonen 2000, Henttonen \& Wallgren 2001, own unpubl. data). The start of our study coincided with a low-density period for Microtus voles, but later stages saw a return of cyclicity and higher numbers of Microtus.

Bank voles were trapped in all succession stages surveyed here but numbers were the highest, especially during the low phase, in mature (> $100 \mathrm{yr}$ ) stands for all years except 2006. These results are consistent with earlier studies that considered mature forests to be the preferred bank vole habitat (Henttonen et al. 1977, Henttonen 1980, Hansson 1978, 1999, Sundell et al. 2012). Yet, we also found how, in certain years (e.g. 2006), bank voles can reach high densities in young succession stages (cf. Henttonen

Table 3. The best supported GLMM for the effects of forest age on the number of field voles on small quadrats. Estimates are given on a logarithmic scale. SE is the standard error of each parameter estimate, and $\sigma$ is the standard deviation attributable to random effects. The intercept stands for $>100 \mathrm{yr}$, Season Autumn and Phase High combination.

\begin{tabular}{llcc}
\hline Effects & Parameter & Estimate & SE \\
\hline Fixed & Intercept & -4.127 & 0.523 \\
& 3-8 yr & 3.363 & 0.551 \\
& $9-15 \mathrm{yr}$ & 1.959 & 0.573 \\
& 24-30 yr & 0.751 & 0.639 \\
& Phase Low & -2.331 & 0.367 \\
\multirow{5}{*}{ Random } & Season Spring & -2.428 & 0.377 \\
& & N groups & $\sigma$ \\
& Quadrat:Area & 200 & 1.965 \\
& Area & 40 & $<0.001$ \\
& Observation & 2000 & $<0.001$
\end{tabular}



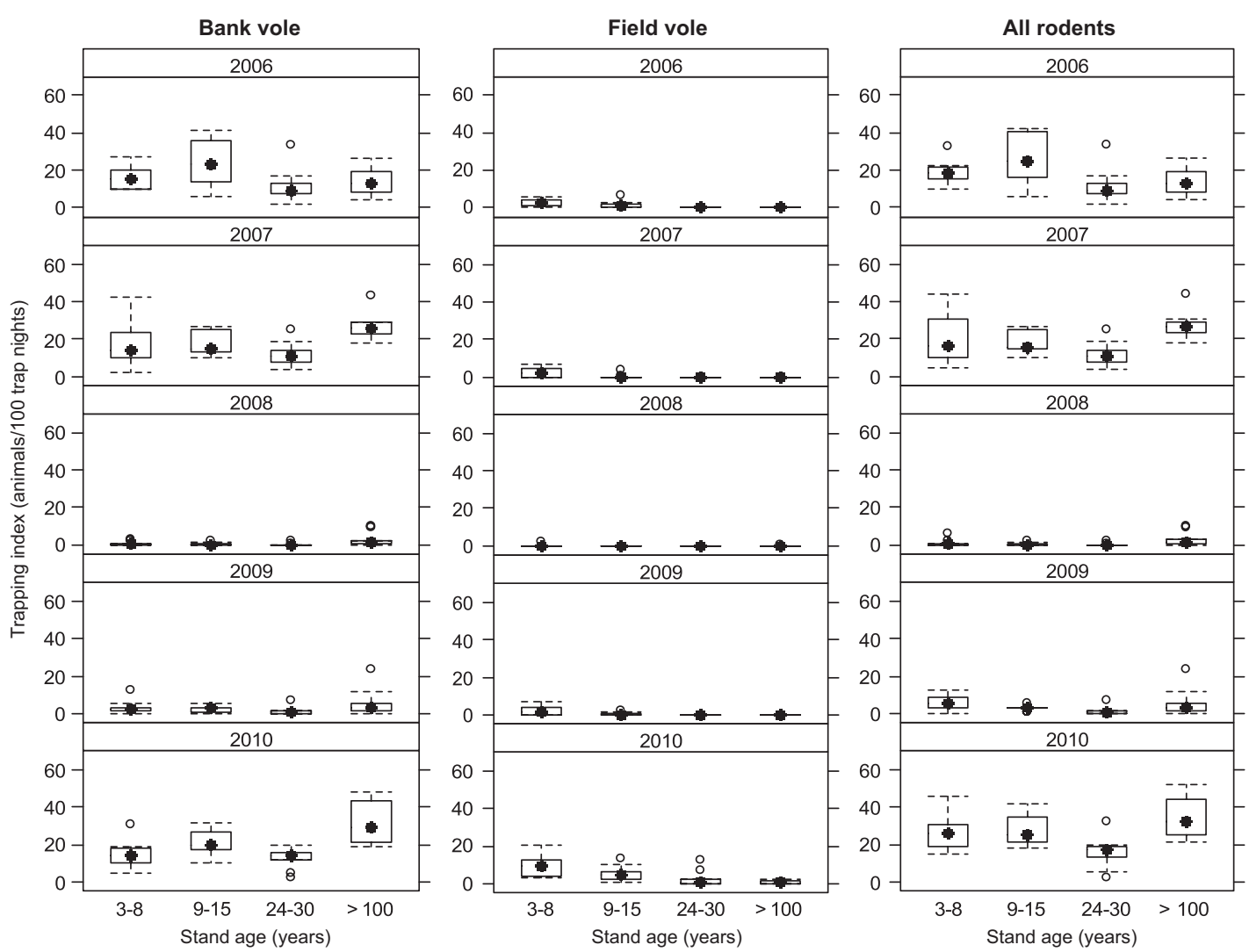

Fig. 5. Trapping indices (animals/100 trap nights) for bank vole, field vole and all rodent species combined in trapping areas in autumn. The smallest value, lower quartile, median, upper quartile, and largest observation are shown.

et al. 1977, Henttonen 1980, Ecke et al. 2002). In spring, breeding bank voles are mainly found in old forests, but during summers of increase and peak years the surplus young spread to younger forest stands. Bank vole indices were higher in 3-8-year-old and 9-15-year-old stands than in 24-30-year-old stands in which also the total rodent density was the lowest found. Our results suggest that the influence of vole density on predator populations is apparent in mature (> $100 \mathrm{yr})$ and young (3-15 yr) forests.

It has been shown that field voles are competitively superior to bank voles (Henttonen et al. 1977, Henttonen 1980, Hansson 1982, Henttonen and Hansson 1984). During 2006-2009, field vole densities in the study area were relatively low, especially during the first peak, and it is likely that bank voles and field voles could be found in the same small quadrats. Models including the effect of Microtus presence performed worse when compared with models excluding them. Our data showed a weak tendency for Microtus presence to have a negative impact on bank voles during the spring. Presumably, this effect would have been more significant if Microtus densities had been higher.

Microtus can reach significantly higher local densities than bank voles (Myllymäki 1977a, Henttonen 1980, 1987). However, our results do not show this pattern, probably because of the long-term low density phase in Microtus. The maximum number of bank voles trapped per quadrat was higher than that of field voles throughout the entire study. However, field vole densities can increase substantially during some ("normal") cycles and create a different situation (Henttonen 1980, Korpimäki \& Norrdahl 1989). Unfortunately, we could not continue this study anymore in 2011, when Microtus densities elsewhere in N Finland reached high densities. It 
must be kept in mind that the home range of the bank vole is considerably larger than that of the field vole, and its probability of being trapped is therefore higher. This means that for equal trapping indices, density of field voles is actually higher.

Population dynamics during the first population peak resembled the seasonal and irregular changes observed in northern Fennoscandia since the 1980s (Henttonen 2000, Hörnfeldt 2004). Vole indices declined drastically during the winters of 2006-2007. Field vole indices were generally low during the first density peak, and earlier studies have also shown low field vole numbers in northern Sweden (Hörnfeldt 2004) and northern Finland (Hanski \& Henttonen 1996) since the 1980s. The second increase and high phase of 2009-2010 were typical of cyclical populations. The vole density index remained at the same level or slightly increased during the winters of 2009-2010. Field voles reached considerably higher numbers in the summer of 2010 than in the summers of 2006-2007 (Fig. 3), and in some stands, field vole indices were higher than those of bank voles.

Due to their ability to form high local densities, Microtus voles are considered a critical factor influencing the reproduction of predators and formation of population cycles in interaction with specialist predators (Henttonen et al. 1987, Hanski \& Henttonen 1996, Henttonen 2000). An increase in Microtus habitat as a consequence of forestry has been implicated as important for small game management in that higher vole densities can support an increase in the predator population. During the study, field vole densities did not quite exhibit classic cycles but showed the importance of young forests to these voles.

In conclusion, field vole densities were highest in the youngest stages of forest succession and thereafter decreased. Overall, the highest numbers of bank voles were in mature forests but they were also abundant in all other stages. Forestry strongly increases the abundance of habitats favoured by field voles and thus has a significant impact on abundance of various vole species and community composition in northern Finland, and is therefore likely to influence the densities of predators and small game.

\section{Acknowledgements}

This study was financially supported by Maj and Tor Nessling Foundation (personal grant to S. S.). Fieldwork in 2006-2008 was financed by the Finnish Game and Fisheries Research Institute, which also provided accommodation in the Taivalkoski aquaculture station. We would also like to thank Pekka Helle for his help during the study, and Liina Voutilainen and Andreas Lindén gave valuable advice on statistical analyses and manuscript. We also thank Janne Sundell and two referees for their valuable comments on earlier versions of the manuscript.

\section{References}

Ahti, T., Hämet-Ahti, L. \& Jalas, L. 1968: Vegetation zones and their actions in northwestern Europe. - Annales Botanici Fennici 5: 169-211.

Angelstam, P., Lindström, E. \& Widén, P. 1984: Role of predation in short-term population fluctuations of some birds and mammals in Fennoscandia. - Oecologia 62: 199-208.

Bates, D. \& Maechler, M. 2009: Ime4: Linear mixedeffects models using $S 4$ classes. - R package version 0.999375-32. [available at http://CRAN.R-project.org/ package $=$ lme 4 .

Burnham, K. \& Anderson, D. 2002: Model selection and multimodel inference: a practical information-theoretic approach. - Springer-Verlag, New York.

Cajander, A. K. 1925: The theory of forest types. - Acta Forestalia Fennica 29: 1-108.

Ecke, F., Löfgren, O. \& Sörling, D. 2002: Population dynamics of small mammals in relation to forest age and structural habitat factors in northern Sweden. - Journal of Applied Ecology 39: 781-792.

Elston, D. A., Moss, R., Boulinier, T., Arrowsmith, C. \& Lambin, X. 2001: Analysis of aggregation, a worked example: numbers of ticks on red grouse chicks. Parasitology 122: 563-569.

Erlinge, S., Hoogenboom, I., Agrell, J., Nelson, J. \& Sandell, M. 1990: Density-related home-range size and overlap in adult field voles (Microtus agrestis) in southern Sweden. - Journal of Mammalogy 71: 597-603.

Ferm, A. \& Sepponen, P. 1981: Aurausjäljen muuttuminen ja kasvillisuuden kehittyminen metsänuudistusaloilla Lapissa 10 vuoden aikana [Development of ploughed tracks and vegetation on reforestation areas in Finnish Lapland during a period of 10 years]. - Folia Forestalia 493: 1-19. [In Finnish with English summary].

Hanski, I. \& Henttonen, H. 1996: Predation on competing rodent species: a simple explanation of complex patterns. - Journal of Animal Ecology 65: 220-232.

Hanski, I., Hansson, L. \& Henttonen, H. 1991: Specialist predators, generalist predators, and the microtine rodent cycle. - Journal of Animal Ecology 60: 220-232.

Hansson, L. 1978: Small mammal abundance in relation to 
environmental variables in three Swedish forest phases. - Studia Forestalia Suecica 147: 1-40.

Hansson, L. 1982: Competition between rodents in successional stages of taiga forests: Microtus agrestis vs. Clethrionomys glareolus. - Oikos 40: 258-266.

Hansson, L. 1999: Intraspecific variation in dynamics: small rodents between food and predation in changing landscapes. - Oikos 86: 159-169.

Hansson, L. \& Henttonen, H. 1985: Gradients in density variations of small rodents: the importance of latitude and snow cover. - Oecologia 67: 394-402.

Hansson, L. \& Henttonen, H. 1989: Rodents, predation and wildlife cycles. - Finnish Game Research 46: 26-33.

Henttonen, H. 1980: Pohjois-Suomen pikkujyrsijöiden yhteisörakenne ja lajien välinen kilpailu. - M.Sc. thesis, Department of Zoology, University of Helsinki.

Henttonen, H. 1987: The impact of spacing behaviour in microtine rodents on the dynamics of least weasels Mustela nivalis - a hypothesis. - Oikos 50: 366-370.

Henttonen, H. 1989: Metsien rakenteen muutoksen vaikutuksesta myyräkantoihin ja sitä kautta pikkupetoihin ja kanalintuihin - hypoteesi [Does an increase in the rodent and predator densities, resulting from modern forestry, contribute to the long-term decline in Finnish tetraonids?]. - Suomen Riista 35: 83-90. [In Finnish with English summary].

Henttonen, H. 2000: Long-term dynamics of the bank vole Clethrionomys glareolus at Pallasjärvi, northern Finnish taiga. - Polish Journal of Ecology 48: 87-96.

Henttonen, H. \& Hansson, L. 1984: Interspecific relations among small rodents in European boreal and subarctic environments. - Acta Zoologica Fennica 172: 61-65.

Henttonen, H. \& Wallgren, H. 2001: Small rodent dynamics and communities in the birch forest zone of northern Fennoscandia - In: Wielgolaski, F. E. (ed.), Nordic mountain birch forest ecosystem: 261-278. Paris and Parthenon Publishing Group, New York and London.

Henttonen, H., Kaikusalo, A., Tast, J. \& Viitala, J. 1977: Interspecific competition between small rodents in subarctic and boreal ecosystems. - Oikos 29: 581-590.

Henttonen, H., Oksanen, T., Jortikka, A. \& Haukisalmi, V. 1987: How much do weasels shape microtine cycles in the northern Fennoscandian taiga? - Oikos 50: 353-365.

Hörnfeldt, B. 2004: Long-term decline in numbers of cyclic voles in boreal Sweden: analysis and presentation of hypotheses. - Oikos 107: 376-392.

Korpimäki, E. \& Norrdahl, K. 1989: Predation of Tengmalm's owls: numerical responses, functional responses and dampening impact on population fluctuations of microtines. - Oikos 54: 154-164.

Korpimäki, E., Norrdahl, K. \& Rinta-Jaskari, T. 1991: Responses of stoats and least weasels to fluctuating food abundance: is the low phase of the vole cycle duet to mustelid predation? - Oecologia 88: 552-561.

Lindén, H. \& Rajala, P. 1981: Fluctuations and long-term trends in the relative densities of tetraonid populations in Finland. - Finnish Game Research 39: 13-34.

Lund, H. M.-K. 1962: The red fox in Norway. I. The feeding habits of the red fox in Norway. - Papers of the Norwegian State Game Research 12: 1-79.

Myllymäki, A. 1977a: Intraspecific competition and home range dynamics in the field vole Microtus agrestis. Oikos 29: 553-569.

Myllymäki, A. 1977b: Demographic mechanisms in the fluctuating populations of the field vole Microtus agrestis. - Oikos 29: 468-493.

Peltola, A. (ed.) 2008: Metsätilastollinen vuosikirja 2008. Finnish Forest Research Institute.

R Development Core Team 2009: $R$ : A language and environment for statistical computing. - $\mathrm{R}$ Foundation for Statistical Computing, Vienna [available at http:// www.R-project.org].

Sirkiä, S., Lindén, A., Helle, P., Nikula, A., Knape, J. \& Lindén, H. 2010: Are the declining trends in forest grouse populations due to changes in the forest age structure? A case study of Capercallie in Finland. - Biological Conservation 143: 1540-1548.

Sundell, J., Church, C. \& Ovaskainen, O. 2012: Spatiotemporal patterns of habitat use in voles and shrews modified by density, season and predators - Journal of Animal Ecology 81: 747-755.

Sundell, J., Huitu, O., Henttonen, H., Kaikusalo, A., Korpimäki, E., Pietiäinen, H., Saurola, P. \& Hanski, I. 2004: Large-scale spatial dynamics of vole populations in Finland revealed by the breeding success of vole-eating avian predators. - Journal of Animal Ecology 73: $167-178$

Uotila, A. \& Kouki, J. 2005: Understory vegetation in spruce-dominated forests in eastern Finland and Russian Karelia: successional patterns after anthropogenic and natural disturbances. - Forest Ecology and Management 215: 113-137.

Viitala, J. 1987: Social organization of Clethrionomys rutilus (Pall.) at Kilpisjärvi, Finnish Lapland. - Annales Zoologici Fennici 24: 267-273.

Viitala, J. \& Hoffmeyer, I. 1985: Social organization in Clethrionomys compared with Microtus and Apodemus: social odours, chemistry and biological effects. Annales Zoologici Fennici 22: 359-371. 